\title{
KVALITATÍV VIZSGÁLAT A KÍGYÓSCSILI TERMÉKEINEK FOGYASZTÓI KÖRÉBEN
}

\author{
Lendvai Edina - Koppányi Kata
}

\begin{abstract}
Absztrakt: Cikkünkben a chili paprika fogyasztását tanulmányoztuk, a Kígyóscsili elnevezésű termékek példáján keresztül bemutatva. Kutatásunkhoz egy kérdőívet állítottunk össze, melyet a Kígyóscsili termékeinek fogyasztói körében töltettünk ki. Öket - többek között - a termékek ízéről, külső megjelenéséről, vásárlási szokásaikról kérdeztük, illetve az árakkal kapcsolatos véleményekről, valamint az új termékekröl. A felmérés alapján SWOT analízist készítettünk, és javaslatokat tettünk.

Abstract: In our article we studied the consumption of chili, by the example of products "Kígyóscsili". We made a questionnaire and it was filled by the consumers of the "Kígyóscsili". We asked them about the taste, the quality, the appearance, purchasing habits and the price of the products. By the basic of our survey we made a SWOT analysis and gave suggestions.
\end{abstract}

Kulcsszavak: csilipaprika, Kígyóscsili, kérdőív felmérés, fogyasztói szokások

Keywords: chili, Kígyóscsili, questionnaire, survey, consumers' habit

\section{Bevezetés}

Napjainkban egyre több és többféle újdonság jelenik meg a magyar gasztronómiában, amiket az amerikai kultúrából veszünk át. Ezeknek az újdonságoknak az egyike a chilipaprikákból készült különböző készítmények: szószok, krémek, savanyúságok, őrlemények és szárítmányok.

Magyarországon hat - hét éve kezdett terjedni a chilipaprikák iránti érdeklődés, mely mostanra már odáig nőtte ki magát, hogy egy, vagy akár több napos rendezvényeket is szerveznek a témában. Hazánkban tavaly ősszel immár a hatodik alkalommal rendezték meg a Solymári Chili Fesztivált, melyen 2016 óta a legjobb chiliszószokat is díjazzák. Nagymaroson pedig 2017 augusztusában ötödjére szervezték meg a Nagymarosi Csípős Fesztivált. Mellettük megjelennek kisebb és fiatalabb fesztiválok is, mint például a Szegedi PaprikaShow és Chili Weekend vagy az „Erös Hajdú” Országos Chili fesztivál Hajdúböszörményben.

De nemcsak a rendezvények mutatják meg a chili egyre nagyobb népszerüségét, hanem az újabb és újabb termelők megjelenése is. Többségük a saját maguk által termesztett paprikákból készíti el a különböző termékeiket saját receptúrájuk alapján.

Tanulmányunkban célul tüzzük ki, hogy minél átfogóbb képet kapjunk a chilipaprika fogyasztásáról, vásárlói szokásokról, preferenciákról, ismeretekről.

\subsection{A chilipaprikáról általában}

Észak - és Dél - Amerika legrégebben termesztett növényei közé tartozik a chili, mely bár zöldség, föként füszernövényként használjuk a konyhában, egyes perui régészeti leletek szerint már 3000 éve. (Somos, 1981)

A chili paprika öt fajba sorolható a Capsicum nemzetségen belül. Ezek a következők (DeWitt-Bosland, 2009):

- Capsicum Annuum (közönséges paprika)

- Capsicum Baccatum (bogyós paprika) 
- Capsicum Chinese (kínai paprika)

- Capsicum Frutenscens (cserjés paprika)

- Capsicum Pubescens (szőrös paprika)

A fent felsorolt öt családnak jelenleg több, mint kétezer fajtáját termesztik megszámlálhatatlan változatban.

\section{1. ábra: Scoville skála paprikafajtákkal}
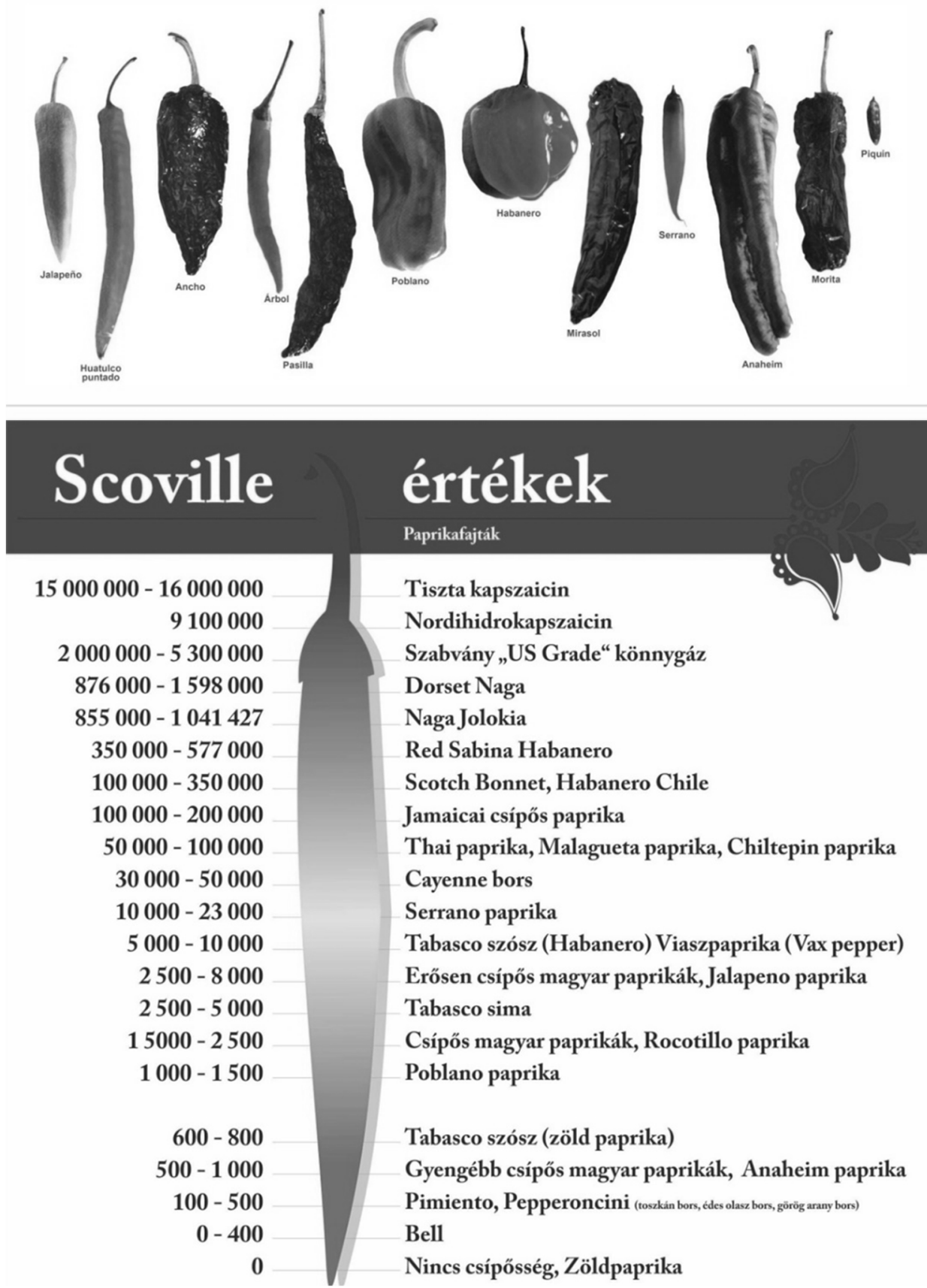

Forrás: betyarchili.blog.hu, 2016 
A chili fogyasztásának és különböző módokon történő felhasználásának rendkívül sok előnyös hatása van, hála a kapszaicin tartalmának. Ez az anyag föként a chili termésének ereiben és a magokban található meg, ő felelős az adott növény csípősségéért (Zatykó, 1978) A paprikafajta csípősségét a Scoville - skálán (1. ábra) adják meg, melynek értékét SHU-ban (Scoville heat unit) adják meg. Az édes paprikák többsége, mint a zöldpaprika 0 SHU értékkel rendelkezik, a magyar csípős paprikák 1500 - 2500 SHU értékkel, míg a világ egyik legerősebb paprikája, a CarolinaReaper 1400000 - 2200000 SHU értékkel bír (chilifutar.hu, 2017). A kapszaicin nem oldódik vízben, így az általa okozott égető érzést nem is lehet vízzel vagy vízivással enyhíteni. Erre a legalkalmasabb a tej, a sajt, vagy bármilyen tejtermék. A vegyület a száj nyálkahártyájával érintkezve az idegeken keresztül olyan jelzéseket ad le az agynak, ,,mint amikor $43^{\circ} \mathrm{C}$ fölötti étel kerül a szájba.” A fájdalom hatására endorfin kezd termelődni a szervezetben (Braun, 2015). Amellett, hogy a kapszaicin zsírégető és étvágycsökkentő hatásának köszönhetően segíti a fogyókúrát, serkenti az anyagcserét is, és fájdalomcsillapítóként is jól müködik. (Ornes, 2010).

\section{2. Újkígyós - Kígyóscsili}

Újkígyós gróf Wenckheim József Antalnak köszönhetően alapult meg az 1810-es években. A gróf földterületeire Szegedről próbált dohánykertész családokat telepíteni, hogy megmủveljék az elvadult pusztákat és mocsarakat. (ujkigyos.hu, 2017) Az idetelepült családok leszármazottai lakják azóta is a települést, melyet 2009. július 1-én nyilvánítottak várossá. (KSH, 2016).

A Kígyóscsili ötlete onnan indult ki, hogy az ötletgazdák, Bánfi Krisztián és családja nem találtak maguknak Békés megyében és környékén hasonló termékeket, és szerettek volna megjelenni ezzel a piacon. Hobbiként kezdték el négy évvel ezelőtt pár növénnyel, amelyek az extra erős kategóriába tartoztak, mint a Trinidad moruga scorpion, ami $1300000-1800000$ SHU erösségü. Ezekből a növényekből készítettek kísérletezésképpen szószokat és krémeket, amiket ők maguk, barátok, családtagok és munkatársak is megkóstoltak. A kezdeti nehézségek óta két éve foglalkoznak komolyabban a termesztéssel, gyártással (Bánfi, 2018).

\section{Anyag és módszer}

Kutatásunk során a Kígyóscsili nevü vállalat fogyasztóinak készítettünk kérdőívet. A válaszadókkal papír alapon, illetve internetes kérdöív formájában töltettük ki a kérdéssort, mely 26 kérdésből állt. A kérdőív 2017. október 1-étől 2018. augusztus 5-éig volt elérhető online, melyet a Facebook segítségével terjesztettünk. A papír alapú kérdőíveket vásárokon és a termelőnél helyben töltettük ki.

A válaszadókat többek között a termékekről és megítélésükről, a versenytársakról, illetve a vásárlási és fogyasztási szokásaikról kérdeztem, majd a kérdőív végén demográfiai adatokat gyüjtöttünk. Azért, hogy minél többen töltsék ki a kérdőívet a Kígyóscsilivel együtt egy nyereményjátékot hirdettünk meg, melyben a termék logójával ellátott pólót és egy szószt nyerhetnek a kitöltők. A kérdőívek kiértékelése Microsoft Excel programmal történt. 


\section{Eredmények és értékelésük}

A továbbiakban néhány fontosabb kérdésre adott választ ismertetünk.

A Kígyóscsili termékei közül a leginkább kedveltet kellett bejelölni, ezt összegzi a 2. ábra. Az elsődleges kedvenc a Smokey BBQ, mely magasan kiugrik a többi közül. A Pickled Jalapeno és a Fruit and Chili Hot Sauce egyaránt kb. azonos kedveltségi szinten van.

\section{2. ábra: A válaszadók megoszlása a termékek kedveltségét illetően. $\mathbf{N = 1 5 5}$}

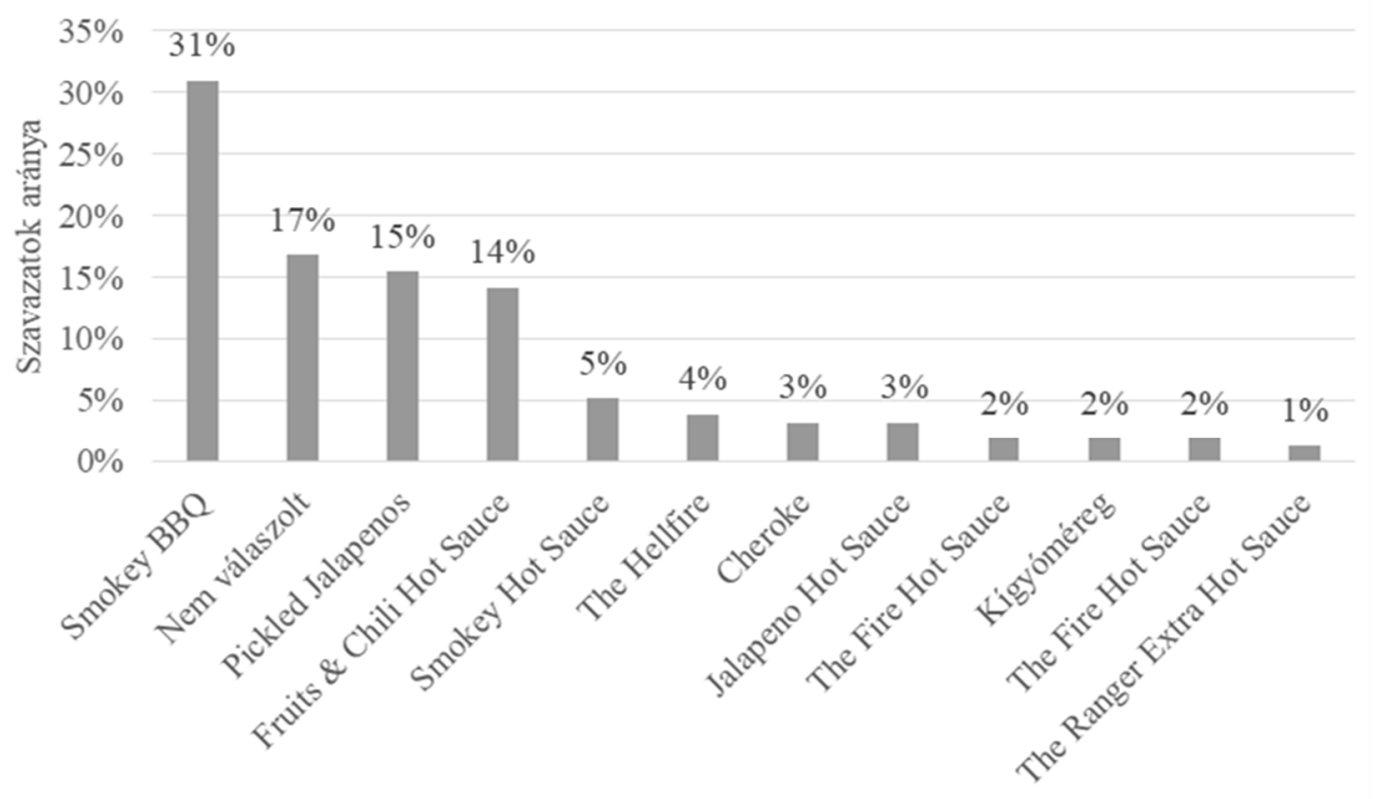

Kedvenc Kígyóscsili termék

Forrás: A szerzők saját szerkesztése.

A megkérdezettek 92\%-a úgy érzi, a termékek beváltották a hozzájuk füzött elvárásokat. Ugyanakkor arra volt már példa, hogy valamelyik kóstolt termék nem nyerte el a vásárlók tetszését (12\%), mert pl. a csípősségét nem érezték megfelelőnek.

Jó hír a vállalat számára, hogy a megkérdezettek mintegy 60\%-a nem ismer versenytársat. Emellett $12 \%$ ugyan ismer más vállalatot, de még nem vásárolt tőlük semmit. Kb. $78 \%$ vallotta magát visszatérő vásárlónak. Általában 3-4 havonta vesznek új terméket, ez elsősorban a fogyasztás miatt valószínủ. A beszerzések során a legnagyobb arányban (47\%) a kitöltők saját maguknak vásárolják a termékeket, $33 \%$ a családjának, $12 \%$ a barátjának és $4 \%$ ismerősnek. A maradék 3\% ajándékozási szándékból vett a szószokból. A kitöltők $24 \%$-a sült húsokhoz fogyasztja a szószokat. 20\% grillételekhez, 18\% pörkölthöz. 11-11\% használja a termékeket levesek, hamburgerek és szendvicsek ízesítéséhez. Az egyéb kategóriát 3\% jelölte meg, itt a rántottát, pirítóst és a nudlit nevezték meg. 
A Kígyóscsilinél folyamatosan jelennek meg új termékek. Arra voltunk kíváncsiak, a kitöltők ismerik - e ezeket. Mint kiderült, 64\% nem ismeri az új termékeket, $17 \%$ ismeri és már kóstolta is, $6 \%$ vásárolt is a készítményekből, $13 \%$ pedig csak hallott róluk. Úgy gondoljuk, megtaláltuk a felmérés legsarkalatosabb pontját. Ez a válasz megmutatja a termékekkel kapcsolatos „leggyengébb láncszemet".

Felmértük a termékek árával való elégedettséget is. Szerintünk más esetben ilyen magas elégedettséggel nem találkozhattunk még, 4,19-os átlagpontszámot ért el ez a faktor (1-5-ig lehetett értékelni), mely azt mutatja, hogy a vásárlók igencsak elégedettek a termékek árával is.

A válaszadók $85 \%$-a lojálisnak tünik a Kígyóscsili produktumaihoz, hiszen akkor sem venne más gyártótól ilyen jellegü készítményt, ha az olcsóbb lenne.

$\mathrm{Az}$ is fontos a vállalkozó számára, hogy a vásárlóik honnan szerzik a termékekkel kapcsolatos információkat (3. ábra). Mint kiderült, a termelőtől, a közösségi médiából, illetve rendezvényeken jutnak fontos infókhoz a válaszadóink.

\section{3. ábra: A válaszadók megoszlása az információk forrása alapján. $\mathbf{N}=155$}

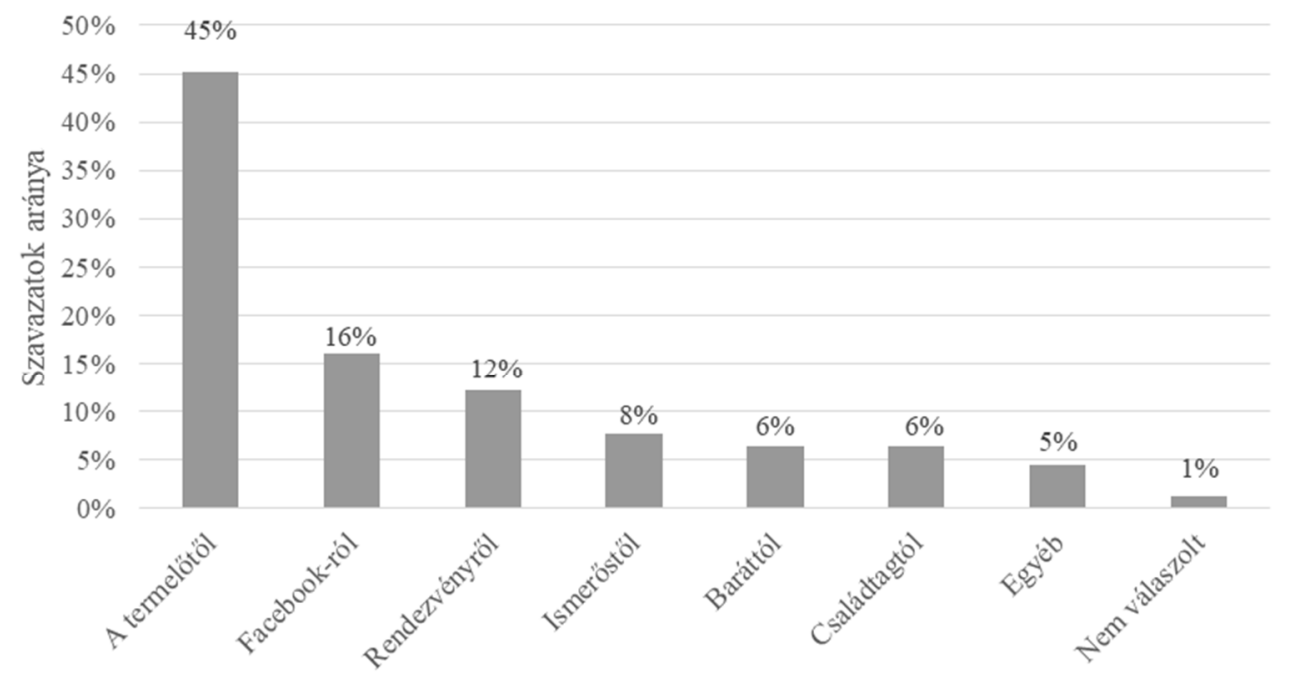

Értesülés a termékekröl

Forrás: A szerzők saját szerkesztése.

\section{Következtetések, javaslatok}

Kutatásunk összegzésével egy SWOT analízist készítettünk, melyet az 1. táblázat foglal össze. Javaslataink (Lehetőségek) között szerepelnek az alábbiak:

- A fogyasztók többsége sült húsokhoz és grillételekhez veszi a termékeket, emiatt érdemes lehet a chiliszósz készítést vendéglátáshoz kapcsolni.

- Mivel a kérdőív válaszadóinak több, mint fele nem ismerte az új termékeket, így azok marketingjére nagyobb hangsúlyt kell fektetni. 
- Szintén nagyobb figyelmet kell fordítani a versenyeredményekre, hiszen, ha nagyobb körben terjed el a jó szereplések híre, nagyobb vevői kör alakulhat ki.

- Az újabb bővítésekkel, úgy, mint gépesítés, munkaerő felvétel és új földterületek vásárlása, nagyobb eséllyel szolgálhatja ki a vállalkozás a vásárlók igényeit.

\section{1. táblázat: A Kígyóscsili és termékeinek SWOT analízise}

\begin{tabular}{|c|c|}
\hline Erősségek & Gyengeségek \\
\hline $\begin{array}{l}\text { - } \quad \text { kedvező földrajzi elhelyezkedés } \\
\text { - jó termöképességü föld } \\
\text { - } \text { magas fogyasztói elégedettség } \\
\text { - } \quad \text { pozitív visszhang } \\
\text { - } \quad \text { széles termékskála } \\
\text { - } \quad \text { vevői hüség } \\
\text { - } \quad \text { versenyeredmények }\end{array}$ & $\begin{array}{l}\text { - } \text { nincs nagy múltja, hagyománya } \\
\text { a magyar gazdaságban } \\
\text { - } \text { stratégiai irány meghatározása } \\
\text { - } \text { nincs olyan nagy szakmai } \\
\text { tapasztalat, mint más } \\
\text { termékeknél } \\
\text { - tapasztalathiány } \\
\text { menedzsmentben } \\
\text { - korszerủ eszközök hiánya } \\
\text { - túlkereslet } \\
\text { minőségromlás }\end{array}$ \\
\hline Lehetőségek & Veszélyek \\
\hline $\begin{array}{l}\text { - tevékenységek összekapcsolása } \\
\text { (BBQ és grill ételek készítése, } \\
\text { falusi vendégasztal) } \\
\text { - nagyobb hangsúly az új } \\
\text { termékek marketingjén } \\
\text { - versenyeredmények kiemelése } \\
\text { - bővítések } \\
\text { ○ földterület } \\
\circ \text { munkaerő } \\
\text { ○ gépesítés }\end{array}$ & $\begin{array}{l}\text { - } \quad \text { klímaváltozás veszélyei } \\
\text { - nem megfelelö hőmérséklet } \\
\text { - növények megbetegedése } \\
\text { - } \quad \text { versenytársak megjelenése }\end{array}$ \\
\hline
\end{tabular}

Forrás: A szerzők saját szerkesztése.

\section{Irodalomjegyzék}

Bánfi K. (2018): Szóbeli közlés

betyarchili.blog.hu (2016): Rekorder chili, Capsaicin, Scoville-skála. Betyár-chili blog. <https://betyarchili.blog.hu/2016/02/09/rekorder_chilik_capsaicin_scoville-skala_kevert_cikk> (2017.10.10.)

Braun T. (2015): Gasztromazohizmus - Csilipaprika-kémia. a Scoville-skála és az ízcsípősségi világrangsor, Magyar Kémikusok Lapja 70(3), 84-87

chilifutar.hu (2017): Egészségmegőrzés. Chilifutár Baráti Kör honlapja. $<$ http://chilifutar.hu/?page_id=171> (2017.10.10.)

DeWitt D., Bosland P. W. (2009): The Complete Chile Pepper Book, Timber Press, London 18-35. 
KSH (2016): Magyarország közigazgatási helynévkönyve, jan. 1., Központi Statisztikai Hivatal, Budapest 28, 100

Ornes, S. (2010): A pepper part that burns fat. Science News for Students, Society for Science \& the Public. <https://www.sciencenewsforstudents.org/article/pepper-part-burns-fat> (2018.10.10.) Somos A. (1981): A paprika, Akadémiai Kiadó, Budapest 15.

ujkigyos.hu (2017): Újkígyós város honlapja <http://ujkigyos.hu/varos> (2017.10.10.)

Zatykó L. (1978): Paprikatermesztés, Mezőgazdasági Kiadó 22-24. 